
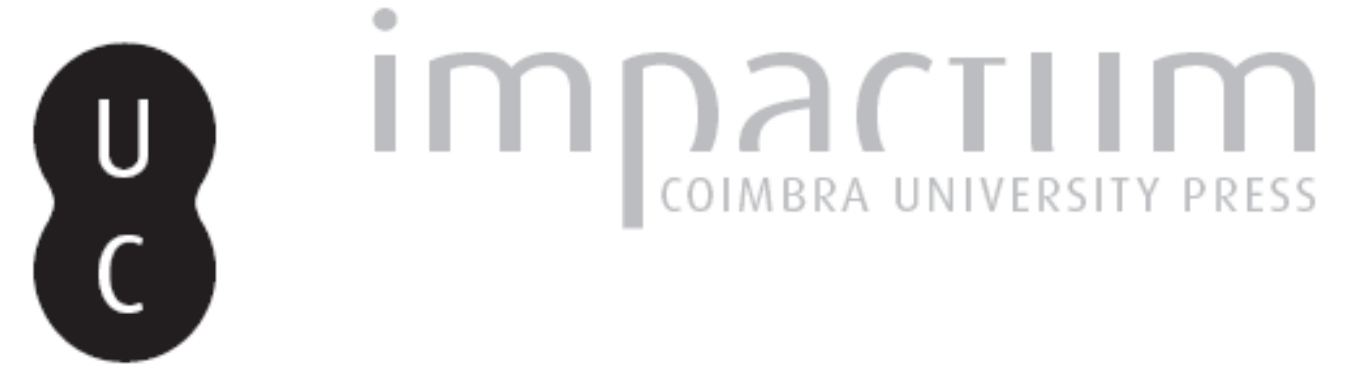

\title{
Avanço cultural e avanço maçónico: segunda metade do século XVIII
}

Autor(es): Dias, J. S. da Silva

Publicado por: Imprensa da Universidade de Coimbra

URL persistente:

URI:http://hdl.handle.net/10316.2/43978

DOI: $\quad$ DOI:https://doi.org/10.14195/2183-8925_1_10

Accessed : $\quad$ 26-Apr-2023 11:45:41

A navegação consulta e descarregamento dos títulos inseridos nas Bibliotecas Digitais UC Digitalis, UC Pombalina e UC Impactum, pressupõem a aceitação plena e sem reservas dos Termos e Condições de Uso destas Bibliotecas Digitais, disponíveis em https://digitalis.uc.pt/pt-pt/termos.

Conforme exposto nos referidos Termos e Condições de Uso, o descarregamento de títulos de acesso restrito requer uma licença válida de autorização devendo o utilizador aceder ao(s) documento(s) a partir de um endereço de IP da instituição detentora da supramencionada licença.

Ao utilizador é apenas permitido o descarregamento para uso pessoal, pelo que o emprego do(s) título(s) descarregado(s) para outro fim, designadamente comercial, carece de autorização do respetivo autor ou editor da obra.

Na medida em que todas as obras da UC Digitalis se encontram protegidas pelo Código do Direito de Autor e Direitos Conexos e demais legislação aplicável, toda a cópia, parcial ou total, deste documento, nos casos em que é legalmente admitida, deverá conter ou fazer-se acompanhar por este aviso. 


$$
\text { INSTITUTO DE HISTÓRIA E TEORIA DAS IDEIAS }
$$

\title{
REVISTA DE HISTÓRIA $D A S$ IDEIAS
}

\author{
VOL. I
}

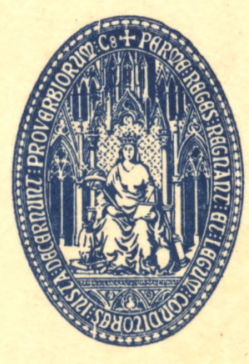

UNIVERSIDADE DE COIMBRA 


\section{AVANÇO CULTURAL E AVANÇO MAÇÓNICO SEGUNDA METADE DO SÉCULO XVIII*}

1. Foi de proporções modestas, em termos de quantidade ou de qualidade, o relançamento da maçonaria em Portugal no segundo período do consulado pombalino. E não se mostra que o pombalismo, como tal, esteja implicado nele. Nem se mostra, por outro lado, que a Sociedade, então ou nos primórdios da época mariana, tivesse funcionado como estrutura produtora ou, sequer, disseminadora da ideologia das Luzes ou do Liberalismo. A implantação dessa ideologia nas expressões portuguesas da Ordem foi um fenómeno lento e de arrastamento nos anos noventa do século XVIII. E foi-o, mesmo assim, sem uniformidade no conjunto das lojas.

PERSISTÊNCIA DO MAÇONISMO NOS ANOS OITENTA

2. Não há indícios de uma expansão significativa do maçonismo no nosso país durante o período que vai da constituição do Grande Oriente de França (1773) até ao surto revolucionário de 89 . É um período, poderemos dizer, em que o movimento do filosofismo e dos ideais revolucionários, modesto aliás, se processou em Portugal à revelia do poder maçónico. Nada nos autoriza, pelo menos, a ver nas estruturas organizativas da Ordem a alavanca ou, mesmo, só uma alavanca do revolucionarismo cultural ou político entre nós.

A expansão da maçonaria no território português não acompanhou o ritmo do seu crescimento na França, na Inglaterra ou nos

* Excerto do volume $1 .^{\circ}$ do livro Os primórdios da maçonaria em Portugal, de aparição iminente. 
Países-Baixos, durante os vinte anos que precederam os acontecimentos de 1789. E não foi também uma sequela desses acontecimentos ou o produto da actuação dos seus agentes no exterior. O fenómeno começou a manifestar-se nos finais da década de oitenta e tomou vulto nos alvores da década de noventa, aliás desordenadamente e sem correspondências ideológicas ou políticas relevantes com o iluminismo ou o jacobinismo. Estas correspondências só de vagar, com o avanço do último decénio, adquiriram importância.

Há provas de que o fogo maçónico não estava completamente extinto pelos anos de 1780-1789. Por cerca do primeiro deles, Barthélemy Andrieu du Bouloy dava, na Madeira, alguns passos no caminho pedreiral. E pouco antes do segundo, organizava-se em Lisboa a primeira loja maçónica de nacionais que se pode documentar (1).

3. Com o regresso de Barthélemy Andrieu du Bouloy ao Funchal, em 1777 (2), produziu-se um condicionamento decisivo para o recomeço das actividades maçónicas na Madeira. Andrieu foi ali encontrar Francisco Xavier de Ornelas ( ${ }^{3}$ ) e outros Irmãos dos anos passados (4). Juntou-se-lhes D. José de Brito Leal Herédia, de regresso ao Funchal, vindo de Londres, já em 1770, e uma década mais tarde denunciado ao Santo Ofício pelo seu activismo maçónico (5). Juntou-se-lhes

(1) Veja-se o capítulo seguinte deste livro, onde o tema é tratado desenvolvidamente.

(2) «.... e voltando o dito reo outra vez para esta Ilha, em companhia do governador actual [João Gonçalves da Câmara], se acha nella por capitão de Artilharia, assistente no forte do Pico, desta vila, com os seos soldados....» (ANTT, Inquisição de Lisboa, Processo n. ${ }^{\circ} 7858$, fls. $14 \mathrm{v}-15$, depoimento de António Bernardo Ferreira e Vasconcelos, porta-bandeira da Companhia, de 23 de Fevereiro de 1780).

(3) Andrieu dá-o, terminantemente, como já mação em 1770 (vid. infra, vol. 2. ${ }^{\circ}$, relatório de Manuel Gonçalves de Miranda cit.). Vicente Júlio Fernandes hesitou, em 1793, em considerá-lo o mestre de cujas mãos recebeu o juramento por $1784 / 1785$, mas dá-o em todo caso como presente na cerimónia (ANTT, Inquisição de Lisboa, Processo $n .^{\circ} 17569$, fl. 1 , confissão de 18 de Abril de 1793). Estes testemunhos são confirmados pelo de João António Ribeiro de Freitas, em 1778, reportado ao ano de 1770 , em que era secretário do governo da Madeira (ANTT, Inquisição de Lisboa, Caderno 130 do Promotor, fl. 127v).

(4) Além de Andrieu, de Ornelas, de Nuno de Freitas, dos companheiros de iniciação e do P. João Martins, Vicente Júlio Fernandes refere ainda, genericamente, «muitos outros», em cujo número inclui, sem dúvida, os seis dignitários da loja (ANTT, Inquisição de Lisboa, Processo n. ${ }^{\circ}$ 17569, fl. 2v).

(5) CABRal do NaScimento, Os pedreiros livres na Inquisição cit., p. 32. 
também, mas talvez um pouco depois, Aires de Ornelas Frazão. As testemunhas ouvidas no processo inquisitório (1779) são quase unânimes em suspeitar Andrieu de ocupaç̃es pedreirais depois do retorno à Ilha (1).

Não pode duvidar-se, pois, de que o francês estabeleceu a breve trecho o contacto com o antigo grupo. Por 1784 ou $1785(2)$, já se faziam admissões na loja (3), contando-se entre elas as de Nuno de Freitas da Silva e Vicente Júlio Fernandes $\left.{ }^{4}\right)$. Pertenciam então à loja, além de Andrieu, de Brito e dos Ornelas, os sargentos-mores Francisco João Barreto e António Alberto Perdigão (5). Dois anos

(1) ANTT, Inquisição de Lisboa, Processo $n .^{\circ} 7858$, fls. 2, 6, 9v, 10v, 11v, $12 \mathrm{v}, 13 \mathrm{v}, 14 \mathrm{v}, 15 \mathrm{v}$, depoimentos de António Francisco Martins Pestana, Manuel Mendes da Silva, João António Rodrigues Jardim, Pantaleão de Sá, João Teixeira da Silva, Manuel João de Gouveia, António da Costa Drumond, António Bernardo Ferreira e João Luís Pestana, todos de 1780.

(2) «Declara ter entrado na Sociedade dos pedreiros livres haverá outo para nove annos» (ANTT, Inquisição de Lisboa, Processo $n .^{\circ}$ 17569, fl. 1, confissão citada de Vicente Júlio Fernandes).

(3) Talvez já desde antes, embora sem possibilidade de o documentar. O mestre D. José de Brito havia regressado à Ilha por 1770 e lá se conservou até 1792 . Em 5 de Abril de 1770, testemunhas ouvidas pelo comissário do Santo Ofício não só confirmam a sua presença na cidade madeirense, mas atestam a sua reputação pública de mação (ANTT, Inquisição de Lisboa, Processo n. ${ }^{\circ} 12515$, fls. 1v, 2 e 3v).

(4) ANTT, Inquisição de Lisboa, Processo $n .^{0} 17569$, fls. 1 e $2 \mathrm{v}$, confissão cit. de Vicente Júlio Fernandes.

(5) Idem, ibidem. O nome completo figura no processo de Gregório Freire Carneiro, onde se especifica que era natural de Lisboa, professo na Ordem de S. Bento de Avis, e partira pelos fins de 1790 para a Madeira como sargento-mór (ANTT, Processo $n^{\circ}$ 3757, fl. 10v). Pertencia já então à maçonaria: «.... contrahio estreita amizade com hum sargento-mór da Ilha da Madeira, chamado Antonio Alberto de Andrade Perdigão, professo na Ordem de S. Bento de Avis, natural desta corte, de donde partio haverá hum anno para a sobredita Ilha, onde ao prezente rezide. E vindo elle hum dia a sua casa o achou lendo em hum livro portuguez intitulado Cathalogo das perseguições da igreja [salvo erro, o Supplemento da historia chronologica dos papas, emperadores e reys, de D. João Evangelista, cujo tomo 2.0 da parte $1 .^{\mathrm{a}}$ se intitula Noticia historico-chronologica das perseguições da igreja], que em hum dos seus capitulos trata de pedreiros livres, e chegando a este lhe dice o mencionado sargento-mór que nesta parte se enganava o author, porque os pedreiros livres em parte alguma se encontravam com a religião, antes o seu instituto os prohibia de tocarem em pontos de religião e de estado, chegando athé a commeter culpa merecedora de castigo todo aquelle que alterasse esta ordem, do que elle tinha pleno conhecimento, pois era hum dos membros desta Sociedade» (Idem, fls. 10v-11). Sabemos pela confissão de Vicente Júlio que estava incorporado na loja madei- 
mais tarde, havia novos ingressos, tendo a loja por venerável Francisco Xavier de Ornelas ( ${ }^{1}$ ). Nos meados de 1789, entrou pelo menos o P. João Pereira da Silva (2).

Quando Vicente Júlio Fernandes foi recebido na loja madeirense, esta funcionava já com bastante regularidade, embora no cerimonial acusasse alguma influência francesa. Traduzem essa influência a presença do Irmão Terrível (desconhecido na Inglaterra) entre os seus oficiais, o uso da espada e do cordão de seda azul, a existência do gabinete de reflexão e, enfim, o cenário tétrico da iniciação, em maré de favor na França, mas assás distante da prática vigente na pedraria orangista e na sua filial lisboeta, a fraternidade de Coustos (3), como já se sabe.

Vicente tem uma referência directa ao Irmão Terrível, mencionando-o entre os oficiais já existentes na loja quando fez a sua iniciação (4). Refere-se também, com circunstância, à ornamentação dos mações $\left(^{5}\right)$. A tudo excede porém o que relata acerca da tetricidade da cerimónia iniciática:

«.... que nesta entrada [ = iniciação como aprendiz] o pozerão em huma pequena caza [= gabinete de reflexão] do mesmo forte [do Gorgulho], deixando-o só

rense, com o grau de mestre, desde data anterior à sua iniciação maçónica (ANTT, Inquisição de Lisboa, Processo $n .^{\circ} 17569$, fls. 1 e $2 \mathrm{v}$ ). E sabe-se ainda que, durante a permanência de serviço ou, mais provavelmente, de interesse particular em Lisboa, frequentou com certa assiduidade as lojas da capital (ANTT, Inquisição de Lisboa, Processo $n .^{\circ} 8615$, fls. 15 e 18$)$.

(1) Confissão de Miguel de Carvalho, apud Cabral do Nascimento, ob. cit., pp. 35-36.

(2) ANTT, Inquisição de Lisboa, Processo $n .^{\circ} 8613$, fl. 1v. Iniciou-se na assembleia reunida em casa de Alder.

(3) Vid. infra, vol. 2., pp. 54-55.

(4) ANTT, Inquisição de Lisboa, Processo n. ${ }^{\circ}$ 17569, fl. 5, confissão cit. de Vicente Júlio Fernandes.

(5) «.... e que neste segundo [ = acto de iniciação no grau de companheiro] estavam os assistentes toudos com aventais de plica branca, e na falta de plica servia hum lenço branco, e com fitas pendentes do pescouso em que via as insignias da masonaria, que são esquadro, compaso, etc.» (Idem, fl. 3); «.... e que, lansando-o sobre o mesmo tumulo fingido [=- desenhado no chão], lhe lansarão por cima hum lensol com algumas nodoas de sangue, estando todo coberto com o mesmo lansol até que, passado algum tempo, que já era bastante para se fazer as serimonias ao outro que tomava o mesmo grao, o descobrirão, estando toudos os assistentes com as espadas nuas apontadas para elle.... E que então o vestirão com os seus proprios ornattos, cingindo-lhe hum avental, lansando-lhe huma fitta ao pescouso, ficando constituido mestre como os outros» (Idem, fls. 3v-4; cfr. fls. $2 \mathrm{v}$ e 5 ). 
a si mesmo, sem mais companhia que huma caveira, fazendo-lhe algumas couzas para lhe lembrar terror (1). E que dahi o conduzirão, com os olhos vendados, a outra caza, onde o mandarão viajar dando algumas voltas na mesma caza .... Que no grao de aprendis lhe diceram, istando elle ainda com os olhos tapados, que ali istavam dois copos com licor e hum delles istava envenenado, que pegasse em hum delles e que se elle hia ali com animo de não ser verdadeiro mason e só por corosidade sertamente pegaria no copo com venenno, porem se hia com animo sincero the aconteseria o contrario» (2).

A regularidade da loja madeirense, quanto à estrutura e ao funcionamento, no período anterior à Revolução de 89 , aufere-se de diversas circunstâncias. Temos a primeira na liturgia das iniciaçð̃es, que combina, sem infidelidades notáveis, os preceitos do Rito Emulation e do Rito Francês. Temos outra na cúpula governativa do areópago: dois vigilantes («surveilhantes»), o irmão terrível, o secretário, o tesoureiro e o orador. Os vigilantes instalavam-se em frente do venerável, cada qual junto de sua coluna do templo figurado no chão; no lugar mais próximo da porta, estava, pelas funções que exercia, o irmão terrível; o orador exortava os Irmãos, muito especialmente os novatos, à prática da fraternidade maçónica, da filantropia e da virtude cívica (3).

Estas duas circunstâncias de regularidade eram completadas pela frequência relativa das assembleias e pelo exercício da beneficência (quase inexistente na loja de Coustos): «se lembra de ouvir muitos [discursos] ao Padre João Pereira em semelhantes ocazioins [= entradas ou mudanças de grau na Sociedade]» (4); "se achou presente em muitas asociasoins de entrada de novos Irmãos.... e tambem em alguns ajuntamentos que se fizerão a fim de ademenistração e aplicação da cacha da Sociedade» ( ${ }^{5}$ ).

(1) A narrativa de Vicente Júlio corresponde, de maneira bastante exacta, à prática introduzida na França (cfr. JACQues PIERre, Cabinet de reflexion, in «Dictionnaire universel de la Franc-Maçonnerie» cit., vol. 1. ${ }^{\circ}$, pp. 183-84). A sua existência quando Vicente Júlio foi iniciado garante que Andrieu trouxera a novidade do seu país quando por 1762 veio incorporar-se nas forças armadas portuguesas, sob as ordens do conde de Lippe. É assim da mais extrema probabilidade a vigência do gabinete de reflexão, em 1770, na loja desmantelada por Sá Pereira.

(2) Processo n. 17569 cit., fls. $2 \mathrm{v}$ e 3v-4.

(3) Idem, fl. 4.

(4) Idem, fl. 4.

(5) Idem, fl. 4. 
Não obstante a comparticipação de membros da colónia inglesa nas actividades da loja madeirense, nesta época, como resulta do testemunho de Vicente Júlio, pode assegurar-se que não estava dominada por eles. Mas isso não significa que o facto não constituisse um motivo para a tolerância das autoridades. Juntava-se, naturalmente, às boas relações de Andrieu com o governador D. Diogo Pereira Forjaz, que chegou a ser suspeitado de mação (1). E juntou-se também ao poder local de vários Sócios, pela sua origem familiar e estatuto social.

4. O balanço adquirido pela loja do Funchal nos anos oitenta está na base da larga implantação que alcançou no limiar da década seguinte. No continente, passaram-se de outra maneira as coisas. Os anos oitenta, pelo que respeita aos portugueses, foram pouco menos que anos mortos, do ponto de vista maçónico. Só no fim da década se deparam vestígios de movimentação da Fraternidade. Essa movimentação, acentuada no decénio seguinte, não revela porém conexões com o filosofismo, nem com o jacobinismo, nem com a militância revolucionária.

\section{O AVANÇO DO DEISMO NO NORTE E NO CENTRO DO PAÍS}

5. O surto do deismo e do filosofismo madrugou mais em Portugal do que o surto do maçonismo. É um facto já no decurso dos anos sessenta. Não foi senão porque ele era um facto que o bispo de Coimbra, D. Miguel da Anunciação, o trouxe ao de cima na célebre pastoral de 1768 , procurando identificar a sua causa com a causa do pombalismo. E não foi senão por esse mesmo facto, procurando marcar distâncias entre o pombalismo e o deismo ou filosofismo, que a Real Mesa Censória proibiu, em 1770, a posse ou circulação de umas dezenas de obras veiculadoras do pensamento deista e filosofista, avultando entre elas textos fundamentais dos seus mais abalizados porta-vozes (2). Cherbury, Chubb, Collins, Morgan, Tindal, Toland,

(1) Cabral do Nascimento, ob. cit., pp. 29 e 30.

(2) Cfr. a respectiva lista apud Teófilo Braga, História da Universidade, t. $3 .{ }^{\circ}$, pp. $60-63$. 
figuram prolixamente no rol, a par de Voltaire, Rousseau, Montesquieu, Diderot, D'Holbach, Helvécio, D'Argens, Fréret, etc. Em 6 de Outubro daquele ano, o algoz já queimava publicamente, na cidade de Lisboa, escritos de Voltaire e D'Holbach, juntamente com os de outros ímpios (1).

6. A enchente filosófico-deista manava de três fontes maiores: os centros militares de forte presença estrangeira, a Universidade de Coimbra, e os círculos intelectuais de Lisboa. Dentro desses mananciais só a custo se detectam contactos, aliás insignificativos e raros, com o maçonismo (2).

Um dos focos de onde o livre-pensamento mais jorrou foi a Praça de Valença. Não pode entretanto falar-se da movimentação ideológica valenciana sem, ao mesmo tempo, se falar da movimentação ideológica coimbrã. Vários dos seus principais responsáveis, com José Anastácio da Cunha à cabeça de todos, intervieram, simultânea ou sucessivamente, no círculo de Valença e no de Coimbra, de maneira decisiva (3). E se o lado do magistério estava representado apenas por Anastácio, já o lado estudantil, quer nas Matemáticas e Filosofia, quer nos Cânones e Leis, tinha uma representação numerosa.

O livre-pensamento e o livre-comportamento andavam associados nestes intelectuais. Havia suspeitas de práticas de homossexualismo entre eles, e davam publicidade às relações de alcova com amásias ou prostitutas. A sua conversa era também abertamente libertina. Não só comiam e bebiam, como toda a gente, mas entregavam-se por hábito e exibição aos excessos da comida e da bebida (4). Os

(1) O respectivo documento foi publicado por Teófilo BragA, ob. e t. cit., p. 58. Em 22 de Dezembro de 1775, queimava-se também l.e vrai sens du système de la nature, de Helvécio (Idem, pp. 58-59).

(2) Vid. supra, onde se trata das actividades de Kinselach.

(3) O tema é estudado e a vasta documentação relacionada com ele, em nosso poder, será apresentada no livro que minha Mulher e eu preparamos sobre José Anastácio da Cunha e a crise ideológica portuguesa dos fins do século XVIII.

(4) O próprio José Anastácio da Cunha, solto em várias formas de costumes, não era dos menos viciados em comesainas e bebedeiras. Em Valença, teve, por mais de uma vez, de ser levado em braços para a cama pelos soldados: «Que haverá mais de dez annos, estando na Praça de Valença, fora vizitar, como costumava muitas vezes, o capitão de bombeiros do seu Regimento, Ricardo Muller, protestante, e por ser depois de jentar, já quazi noute, o achou bastantemente alegre e tomado do vinho, e a José Anastácio da Cunha, de quem tem dito em sua confis- 
muitos documentos que à personalidade deles se referem, longe de os recomendarem pela austeridade dos costumes ou a elevação dos sentimentos, deixam de si uma imagem deplorável.

Estes homens sentiam-se, instintivamente, deslocados na ambiência cultural e social do país. Rejeitavam-na por incompatível com as tendências espontâneas do seu espírito. Foi, no entanto, através das leituras, que aprenderam a cultuar a razão, a natureza e a ciência. As leituras deram uma estrutura intelectual ao que era apenas uma repulsa natural.

Documenta-se, na verdade, que manusearam intensamente obras proibidas $\left(^{(1)}\right.$. E se bem, para já, faltem elementos que permitam relacionar a maioria dos autores e textos frequentados, conhecem-se todavia alguns deles. Mostra-se, com efeito, que foram leitores assíduos de Voltaire, tendo circulado de mão em mão o Dictionnaire philosophique portatif, L'homme aux quarente écus, as Mélanges littéraires et philosophiques, além de outras composições não identificadas (2). Leram-se também muito, embora não tanto, as produç̃es

são, totalmente bebado e privado dos sentidos» (ANTT, Inquisição de Coimbra, Processo n. $^{\circ}$ 8081, fl. 15-15v, confissão de José Leandro Melliani da Cruz, de 20 de Janeiro de 1778). "Que aonde diz tivera com Ricardo Muller huma pratica em que este o convidara para ser framason, querendo deitar-lhe ao pescoço hum escapulario branco, elle dicera estava prezente na dita occazião José Anastacio, e inteiramente bebado e privado dos sentidos, declara que logo que elle reo entrara na dita caza o levarão huns soldados para fora, e não sabe se o forão deitar na cama do dito Muller, motivo por que não prezenciou a dita pratica» (Idem, fl. 27-27v, confissão do mesmo José Leandro, de 20 de Fevereiro de 1778).

(1) ANTT, Inquisição de Coimbra, Processo n. ${ }^{\circ} 8087$ (José Anastácio da Cunha), fl. 26v e 70; Processo $n .^{\circ} 8078$ (Aleixo Vache), fl. 49; Processo $n .^{\circ} 8084$ (José Maria Teixeira), fls. $5,5 \mathrm{v}$ e 24 ; Processo $n .^{\circ} 8081$ (José Leandro Meliani da Cruz), fls. 18-20, 22v, 24, 26; Processo n. ${ }^{\circ} 1778$ (José Madeira Monteiro), fl. 7; Processo $n .{ }^{\circ} 8075$ (Henrique Leitão de Sousa); Inquisição de Lisboa, Processo n..$^{\circ} 1740$ (José da Silva Moreira), fl. 11.

(2) ANTT, Inquisição de Coimbra, Processo $n .0^{\circ} 8084$ (José Maria Teixeira), fls. 6, 17, 21v, 22v, 29, 52, 70, 76, 77, 77v; Processo.$^{\circ} 8091$ (Joaquim Vicente Pereira de Araújo), fls. 4, 4v, 5v; Processo $n .^{\circ} 8090$ (Luís José Pereira Freire de Andrade), fl. 8-8v; Processo $n .^{\circ} 8081$ (José Leandro Meliani da Cruz), fls. 6, 21, 25v, 28v; Processo n. ${ }^{\circ} 8085$ (José de Sousa), fls. 8 e 14; Processo n. ${ }^{\circ} 7265$ (José Barreto), fl. 2; Processo $n .^{\circ} 8087$ (José Anastácio da Cunha), fls. 26v, 71, 72, 73v, 74v, 75, 91-94v, 109; Processo . $^{\circ} 8078$ (Aleixo Vache), fls. 8, 11, 13, 24v, 25v-27v, 44, 47v, 63; Inquisição de Lisboa, Caderno 130 do Promotor - denúncias e apresentações, fls. 62, 
de Montesquieu (sobretudo as Lettres persannes), do marquês de Argens, de Rousseau, de D'Holbach (designadamente o Système de la nature), de Helvécio, de Hume, de Pope, de Mirabeau (1).

É palpável que a mediação destas leituras deixou nos seus espíritos marcas ideológicas profundas. $E$ as que mais contam, de entre elas, não são propriamente as teses de ressonância teológica heterodoxa, aliás numerosas, sobre os atributos de Deus, a imortalidade da alma, os imperativos e fundamentos da moral, as relações da igreja e da sociedade, a disciplina eclesiástica, a prática comum dos católicos, o papel e poder do clero, o purgatório, a autoridade da revelação. As notas mais a gudas dessas marcas recaem, antes, na óptica livre-pensadora e deista que os guia na análise do fenómeno religioso cristão e na correspondente tomada de posição polémica em face dele. Deismo, tolerantismo e livre-pensamento andavam de mãos dadas. Só um texto abonatório da tese:

«Dice mais que, haverá treze annos, fizera o dito brigadeiro Ferrier huma composição em verso solto português, que tinha por objecto expor várias loucuras dos homens, com o titulo Veritate Sacrum. E nella louvava os filosofos modernos, como Neuton, Vultaire, Rousseau, e outros, por terem pensado e escripto bem, ainda nas materias tocantes à religião. E na dita compozição apoyava o dito Ferrier não haver couza mais justa que o tolerantismo e o pensar-se livremente e como cada hum quizesse em materias da religião. E que era impiedade e tirania cheigar os homens a captivar os seos entendimentos e discursos a algumas regras, leys e preceitos. E que elle lhe imendou muitos versos desta compozição e lhe acrescentou outros, todos concebidos neste espirito e neste systema, pelo que respeita ao seo fundo, ainda que muitos forão indiferentes e que se dirigião a ridicularizar o methodo escholastico, forma sylogistica antiga, e outros sobre a filosofia de Descartes e outros filosofos a quem criticava»(2).

71, 84. Os processos indicados nesta nota, na anterior e na seguinte, serão publicados, juntamente com outros e vária documentação complementar, no já citado livro que minha Mulher e eu preparamos sobre José Anastácio da Cunha e a crise ideológica portuguesa do século XVIII.

(1) ANTT, Inquisição de Coimbra, Processo n. 8084 (José Maria Teixeira), fls. 12v e 70; Processo n. $^{\circ} 8090$ (Luís José Pereira Freire de Andrade), fls. 8v-9; Processo $n .^{\circ} 7265$ (José Barreto), fl. 2; Processo $n .^{\circ} 8078$ (Aleixo Vache), fls. 8, 44v, 63; Processo n. 8087 (José Anastácio da Cunha), fls. 36, 62v, 73v; Inquisição de Lisboa, Caderno 130 do promotor cit., fl. 71 (apresentação de Jerónimo Francisco Lobo, estudante de Coimbra).

(2) ANTT, Inquisição de Coimbra, Processo n. ${ }^{\circ} 8087$, fl. 73v, confissão de José Anastácio da Cunha, de 1 de Julho de 1778; cfr. fl. 106-106v. 
7. Começou pelos meados dos anos sessenta a militância «filosófica» dos valencianos. E não a poderemos considerar dispicienda, se introduzirmos no cálculo a intelectualização de muitos dos soldados e oficiais que na mesma se empenharam e a participação que estudantes de Coimbra nela tiveram. No plano da Universidade, o movimento do filosofismo acompanhou de perto a chegada de José Anastácio da Cunha e de alguns dos seus amigos de Valença, em 1773. Desencadeou-se imediatamente um processo de fermentação ideológica que não só ia ao revés da cultura dominante, mas se achava em polémica aberta com ela. Devoravam-se os textos dos «filósofos»e dos literatos comprometidos em «filosofia»; sustentavam-se as teses da religião natural e da moral natural; turiferavam-se com a razão e a ciência a natureza e o homem. Punham-se portanto no primeiro plano do pensamento valores e critérios que apontavam para a morte da «forma mentis» legada pela Contra-Reforma.

O iluminismo e o filosofismo abraçavam-se estreitamente no grupo conimbricense. Ao mesmo tempo que pretendiam destruir, com as simples luzes da razão, toda a perspectiva teológica do homem e da cultura, propunham-se (ainda que pouco mais do que em mero subentendido) construir, sobre as ruínas da igreja, uma nova maneira de estar na sociedade e no estado. $E$ enquanto, por um lado, modelavam o discurşo teórico pelos padrões do recente saber científico, primordializavam, por outro, as bases naturais e terrenas da vida humana, dando o estatuto de conquista irreversível da História ao humanismo antropocêntrico e aos seus fieis companheiros de percurso, o individualismo e a visão geocêntrica do mundo (1). Não são ainda ateus, mas a sua religiosidade pára nas fronteiras da religião natural, tal como o deismo a veiculava (2).

O DEISMO EM LISBOA E NA PROVÍNCIA

8. As concepções dos valencianos e conimbricenses circulavam também em Lisboa. Francisco Manuel do Nascimento foi por causa

(1) A análise em que se baseiam as sínteses dos n. ${ }^{\circ} 6$ e 7 será feita no já citado livro José Anastácio da Cunha e a crise ideológica portuguesa do século XVIII.

(2) ANTT, Inquisição de Coimbra, Processo n. ${ }^{\circ} 8087$, fls. 83v, 91-101v; Processo $n .{ }^{\circ} 8090$, fls. 3-5 e 7v-8; Processo $n .^{\circ} 8084$, fls. 5, 5v, 7-9v, 10v-12v, 18-19, $21 \mathrm{v}, 52 \mathrm{v}, 65 \mathrm{v}-67,78 \mathrm{v}$. 
delas objecto de pesquisas no Tribunal da Inquisição (1). $\mathrm{O}$ processo contra o vate animador de um grupo literário-cultural, chamado da Ribeira das Naus, abriu-se em 22 de Junho de 1778, por denúncia do P. José Manuel de Leiva (2). Seguiu-se depois o interrogatório de várias testemunhas. E o réu só não foi recolhido no cárcere inquisitorial, por se ter escapado aos esbirros, com decisão, no momento da captura $\left({ }^{3}\right)$.

Filinto, pelo que declaram os depoentes, aliás com sinais de verosimilhança, era leitor assíduo dos corifeus do filosofismo. Entre eles destacam nominativamente Voltaire e Rousseau (4). Acusam-no também, com boa soma de pormenores, de desvalorizar a autoridade da Bíblia e das definições dogmáticas, proclamando o cânone racional como único critério de verdade no campo religioso. Acusam-no, igualmente, de desfazer nas práticas do culto católico e de sustentar a equivalência dos diversos sistemas de crenças. Embora sem empregarem a palavra, pela rudeza da sua cultura, apresentam indícios mais do que suficientes para os inquisidores o rotularem de deista. E não de um deismo qualquer, mas daquele que se nos apresenta em ingleses como Bolingbroke ou em franceses como Voltaire, Rousseau e D'Holbach.

Francisco Manuel não fazia segredo das suas ideias. Pelo natural comunicativo e desassombrado, patenteava-as, sem rodeios, diante de quem o ouvia ou procurava. É o que se verifica pelas declarações de Francisco Joaquim Moreira de Sá, na sua representação de 6 de Junho de 1780:

«Quazi logo depois que o representante daquella vez [1771/1772] veyo a esta corte, o convidou a gentar, na sua caza, hum homem de negocio chamado Manoel José Cardoso; e entre outros convidados, concorreo hum clerigo chamado Francisco Manoel, desta corte, conhecido aqui por filho ou sobrinho

(1) Acha-se já transcrito o processo deste escritor e publicá-lo-emos, em breve, juntamente com os de Bocage, José Agostinho de Macedo e Belchior Curvo Semedo, com introdução e notas.

(2) O poeta, influenciado pela notícia de prováveis desabafos da mãe, quer antes, quer depois da sua fuga, chegou a supor que teria sido ela quem o denunciou ao Santo Ofício. Cfr. Filinto Elysio, Obras completas, t. 4. ${ }^{\circ}$, Paris, 1818, pp. 146 e 164.

(3) Teófilo Braga, Filinto Elysio, pp. 233-49.

(4) Mencionam ainda um livro que julgo ser a Histoire de toutes les religions $d u$ monde, de Alexander Ross, traduzida do inglês para francês por Th. de la Grue e impresso em Amesterdão, em 1666 e 1669. 
do patrão-mór, cujo Padre dizem estar hoje em França. A instrução que o dito Padre tinha, principalmente de poezia, obrigou o representante a querê-lo tratar. E falando, com efeito, varias vezes, veyo a conhecer evidentemente que o sobredito Padre estava todo occupado e persuadido das ideias do materialismo" (1).

9. O esforço da Real Mesa Censória para acautelar o País contra o risco de "perversão» das inteligências pelo contacto com as fontes da "impiedade» corresponde, ao mesmo tempo, a prevalências do espírito mimético e ao reverbero de factores nacionais. Não o determinaram unicamente as sugestões livrescas dos Bergier, dos Nonnote, dos Valsecchi, e de outros expoentes da polémica internacional contra o deismo, o materialismo e o filosofismo. Determinou-o também - quase diria sobretudo - o fogo que a chispa destas ideias ateava nos círculos da juventude culta e dos intelectuais abertos de Portugal, já nesse tempo.

No ano lectivo de 1777-1778, o deismo e o filosofismo tinham-se tornado moeda corrente nas conversas e disputas entre estudantes de Coimbra (2). A leitura de Rousseau volveu-se então frequente e influenciou muitas sensibilidades (3). Estiveram neste caso José Maria da Fonseca e os seus companheiros Lourenço Justiniano, António Pereira Caldas, Francisco José de Almeida e António Manuel Félix (4). Entre os participantes nessas conversas e discussões, salientavam-se personagens que depois ingressaram na loja maçónica do Funchal (5).

(1) ANTT, Inquisição de Lisboa, Processo $n .^{\circ}$ 16335, fl. 2-2v.

(2) «A origem toda da minha disgraça esteve no $1 .^{\circ}$ anno da Universidade: então hé que os meus ouvidos se costumarão a familliarizar com questoens [à margem: todas as que se envolvem no deismo e ainda a imortalidade da alma ou outras semelhantes] e disputas que, não obstante o speciozo veo da philosophia com que se cobrem, a experiência me mostra o quanto são às vezes perigozas» (ANTT, Inquisição de Lisboa, Caderno 130 do promotor cit., fl. 137, denúncia de José Maria da Fonseca, estudante do terceiro ano de Leis, de 11 de Agosto de 1779).

(3) «A lição de huma parte do Rossó me menistrou novos motivos de tibieza na fé» (Idem, ibidem).

(4) Idem, fls. 137v, 139v, 140, 141. Félix era também leitor de Pierre Bayle.

(5) «Antonio Caetano, Nuno de Freitas e Vicente Jullio assistiram tambem, muitas vezes, e prezencearão as ditas conversas com diligencia; este ultimo menos que os outros» (Idem, fl. 137v). Nesta denúncia e nas que a completam, de 18 e 20 de Agosto, há mais elementos sobre os três madeirenses, que confirmam, sobretudo quanto aos dois primeiros, o seu alinhamento teórico e prático pelo deismo, desdenhando por exemplo o jejum quaresmal. 
Pereira Caldas, de origem brasileira, avultou, seguidamente, como poeta (1). Almeida adquiriu grande reputação como médico; e apesar de ser havido desde cedo por mação, parece só ter ingressado na Ordem em $1821(2)$. No período vintista, manifestou publicamente a sua opção liberal, escrevendo sobre a convocação das cortes (3) e o tribunal dos jurados $(4)$. Acamaradava com estes, nas ideias, António de Morais, o futuro dionarista (5).

10. Há outros sintomas de que as concepções deistas e filosofistas estavam relativamente divulgadas em Lisboa. Denota-o a própria falta de recato com que os seus adeptos as sustentavam e com que até os livreiros as alimentavam. É digno de nota o comportamento do livreiro Borel e do filho de Matias Aires, o autor do Discurso sobre a vaidade dos homens:

«Estando eu, haverá mais de dois annos, na loge de livros de Borel Borel, defronte da igreja de N.S. dos Martyres, desta cidade, se achou ali José Ayres Ramos d'Eça, filho do provedor da Moeda, Mathias Ayres Ramos d'Eça, o qual, na minha prezença e de meu companheiro (que me não lembra quem era) e do dito Borel ou seu companheiro, ou de ambos, dise que diziamos mal de Voltaire e de Rousseau porque os não entendiamos, e acrescentou de um dos dois (não me lembra de qual delles) que era hum grande theologo e que a sua theologia era muito recondita (parece-me que este foi o termo que uzou)» $(6)$.

De Coimbra e de Lisboa, a sensibilização deista trasvasou pela província, embora só timidamente. $\mathrm{O}$ dr. Lourenço José de Medeiros da Silva Carreiro, fixado em Ponta Delgada, assemelha-se não ter esquecido ainda em 1778 o gosto por Voltaire e pela lei natural e, dizendo-se leitor de Justino Febrónio, disputava sobre a autoridade

(1) Fonseca faz-lhe várias referências nas denúncias. Teófilo Braga (Filinto Elysio e os dissidentes da Arcádia, pp. 606-18) também se ocupa dele.

(2) Ver Inocêncio Francisco da Silva, Diccionario bibliographico portuguez, t. $2 .{ }^{\circ}$, pp. $400-401$.

(3) Introdução à convocação das Côrtes, debaixo do juramento prestado pela nação, Lisboa, na Imprensa Régia, 1820.

(4) Breve exposição da instituição do jurado, das suas vantagens e defeitos, $e$ dos melhoramentos de que hé susceptivel, Lisboa, na Imprensa Nacional, 1822.

(5) ANTT, Inquisição de Lisboa, Caderno 130 do promotor cit., fls. 141v e 142.

(6) ANNT, Inquisição de Lisboa, Caderno 130 do promotor cit., fl. 84. 
do papa (1). Mesmo no norte do País, não faltava quem trilhasse os novos caminhos. Era o caso de Manuel Félix de Negreiros (2) e do P. José de S. Bernardino Botelho:

«.... encontrando-se, á outo ou nove annos, na cidade de Braga, em caza do dezembargador Antonio Martinho de Quirós e Vasconcellos, com José de Sam Benardino Botelho, então reytor de Celeirós, da Congregação do Evangelista, e prezentemente reytor de Alijó, e sendo constante a boa reputação deste Padre em materia de leteratura, e principalmente de bellas letras, e não tendo tido o reprezentante educação literaria, dezejando porém tê-la, contrahio logo nessa occazião, que foi a primeira em que se virão, amizade com o dito Padre; the introu a dirigir a carreira dos seos estudos em bellas letras, e lhe foi franqueando e aconselhando a lição de alguns livros prohibidos. O tempo e algumas conferencias forão dezimbrulhando as ideas do dito Padre, de modo que o reprezentante veyo a conhecer claramente que elle estava infestado da gangrena do deismo. Haverá perto de três annos que o denunciante, obrigado de negocios da caza, veyo a esta corte e se hospedou os primeiros dias em caza do sobredito, que nesse tempo estava nesta corte em caza de seo pay, o capitão-mor José Bernardes Pessoa, morador ao Menino Deos, e ahi concorreo com elle pela primeira vez hum Manoel Felis, clerigo minorista, que da cidade do Porto tinha vindo para a caza do marquez de Marialva, com seo filho Dom Rodrigo de Meneses, e debayxo da sua protecção. E porque o reprezentante com este tinha boa amizade, o dito Manoel Felix entrou a frequentar o seo comercio com o fim de que o mesmo denunciante fizesse lembradas a Dom Rodrigo as suas pertençoens, e também por entender que o mesmo denunciante lhe podia ser util com outras proteç̧oens. Durante esta comunicação, conheceo bem que o dito Manoel Felix decididamente abraçava o horrorozo systema do materialismo, e o divulgava e persuadia com o mais extravagante entusiasmo» (3).

(1) ANTT, Inquisição de Lisboa, Processo $n .^{\circ} 5633$.

(2) «.... pelo que pertence ao estado de sua religião, faz formalmente conceito e sempre o fez desde que o conhece, que hé livre. E isto porque frequentava a lição de Voltaire, livro que ordinariamente trazia na algibeira; discorria sobre algumas passagens impias do mesmo author, e comia carne nos dias em que a igreja prohibe o seu uzo,sem que elle depoente conhecesse motivo que o escusasse de culpa; e ultimamente por ouvir dizer a alguns criados da caza do marquez de Marialva, cujos nomes ao prezente lhe não lembrão, que elle era cheio de liberdade e não tinha religião, e como tal era amigo de Manoel Coelho, creado do secretário de estado Ayres de Sá, de quem fazião o mesmo conceito de libertino, como o dito Manoel Felix de Negreiros» (ANTT, Inquisição de Lisboa, Caderno 130 do promotor cit., fl. 62, depoimento de José Joaquim Toscano de Figueiredo e Albuquerque).

(3) ANTT, Inquisição de Lisboa, Processo n. ${ }^{\circ}$ 16335, fl. 1-1v. denúncia de Francisco Joaquim Moreira de Sá, de 6 de Junho de 1780. 


\section{PROPULSÃO E REPULSÃO DAS OPÇõES PROGRESSISTAS}

11. O desenvolvimento da maçonaria em Portugal tem que ver com a fermentação ideológica e a fermentação social em processo no País durante a segunda metade do século XVIII. E estas duas, por seu turno, têm que ver também entre si. Um e outras passaram pelo jogo de travões e de aceleradores do processo global e dos processos sectoriais em actividade no século XVIII português.

No período que vai do fim dos anos sessenta ao fim dos anos setenta deste século, a Real Mesa Censória empreendeu uma vasta campanha contra a penetração ou circulação em Portugal de textos que veiculassem o deismo, o materialismo ou o filosofismo, proibindo-os e explicando por que os proibia (1). A par de obras de figuras cimeiras, como Cherbury, Collins, Toland, Bolingbroke, Espinoza, Voltaire, Montesquieu, Helvécio, D'Holbach, Rousseau, atingiram-se dezenas de outras menos representativas, mas nem por isso menos lidas. O alvo era sustar a invasão do espírito crítico e, por esse meio, garantir a vigência estável das estruturas culturais barrocas, depois de ajustadas e modernizadas pelo iluminismo católico.

Como avisaria Fr. José da Rocha, numa «censura», em 1776

«igualmente perigoso ao estado e à religião é aquele espírito de dúvida e de exame, que.... veio Descartes estabelecer...., sobre todas as ideias e opiniões desde a infância recebidas, e de aqui se seguiu uma grande revolução não só na filosofia e mais ciências humanas, mas também na mesma religião revelada. Daqui se seguiu o exame de todas as seitas, feito pelas fracas luzes da razão natural, a reprovação de todas elas, e a invenção de uma nova que fosse conforme às mesmas escurecidas luzes da razão natural, proporcionada às paixões da natureza corrupta, e que desse uma inteira liberdade aos homens no pensar e no obrar. Tal é o deismo, o naturalismo e o materialismo» (2).

O pensamento enunciado pelo frade é a tese de uma escola e tinha feito já a sua aparição, muitas vezes, em documentos similares. Em 1768, Fr. Inácio de S. Caetano, o futuro arcebispo de Tessalónica e confessor da rainha D. Maria I, arguía Locke de chocadeira do

(1) Elementos capitais dessa actuação foram já apresentados por TeófILo Braga, História da Universidade de Coimbra, t. 3. ${ }^{\circ}$ pp. 48-100, e J. T. DA Silva BasTOS, História da censura intelectual em Portugal, Coimbra, 1926, pp. 149-209.

(2) Apud Teófilo Braga, História da Universidade, t. 3.º p. 49. 
materialismo, «este monstro que tanto domina no século presente, com ruína grande da religião», e apontava para Rousseau como "o chefe dos irreligionários e materialistas deste século» (1). Análises do mesmo tipo são triviais na época.

Pombal não foi senhor de seguir só as preferências teóricas e políticas do iluminismo católico. Teve de aceitar um compromisso histórico que deixava o caminho aberto para os objectivos da ala reformadora, mas pactuava ao mesmo tempo com os sentimentos mais enraizados de uma parte da sua base de apoio, a nobreza secundária e o clero regalista. O equilíbrio instável entre os dois pratos desta balança, as reservas do sector iluminista a certas directrizes que emanavam da Real Mesa Censória, afloram neste passo do depoimento de uma testemunha ouvida no processo inquisitorial de Filinto Elísio, em 1779:

«Disse que havia quatro anos teve conhecimento e amizade com algumas pessoas que sabia tinham uso e lição de alguns livros proibidos, como são Voltaire, Rousseau e outros semelhantes.... E que ele se julgava sem obrigação de os vir denunciar a esta Mesa, por dois motivos: primeiro, porque, ainda que nesse tempo estivesse a porta deste tribunal aberta para receber as denúncias, sabia ele testemunha que eram menos bem olhadas do ministério as pessoas que intentavam as referidas denúncias....» (2).

12. O poder de travagem da Real Mesa Censória mitigou, mas não anulou a propulsão cultural que manava de outras forças. Nos dois para três lustros que antecederam a Revolução Francesa, verificou-se, na verdade, em Portugal, uma certa movimentação ideológica, de sabor deista e filosofista, entre a gente nova. Essa movimentação, especialmente notória em Coimbra e Lisboa, à data os primeiros centros intelectuais da pátria, reflectia o avanço, ou anseio de avanço, das camadas burguesas no sentido do poder político e social. O desenvolvimento das forças produtivas culturais, a superação da cultura hegemónica, eclesiástico-aristocrática, confluía (e não seria revolucionária se não confluisse) com o desenvolvimento das forças produtivas materiais da burguesia, reforçando a sua dinâmica e dando-lhe expressão polémica na área dos suportes ideológicos da sociedade civil (3).

(1) Apud Teófilo Braga, ob. cit., t. 3. ${ }^{\circ}$, pp. 66 e 67.

(2) Apud Teófilo Braga, Filinto Elysio, pp. 264-65.

(3) Emprego a expressão no sentido de Gramsci, contrapondo-a pois à sociedade política, isto é, ao aparelho de estado. Cfr. Hugues Portelli, Gramsci et le bloc historique, Paris, 1972, pp. 13-46. 
A burguesia - melhor será dizer as burguesias - era uma classe extremamente minoritária à escala do País. O seu núcleo mais forte eram o estrato mercantil do litoral e o estrato burocrático. A burguesia agrária e a burguesia artesanal estavam prisioneiras ainda de grandes alienaç̃es. O poder dos sectores burgueses mais evoluídos encontrou um aliado de monta nos intelectuais. Muitos destes saem da própria classe; o seu número é porém muito engrossado pelas franjas ideologicamente (não escrevo socialmente) radicais do baixo clero e da baixa nobreza. Essas franjas tinham-se robustecido muito na luta do pombalismo com o alto patriciado temporal e sacral.

13. O grande passo em frente, ideológico e organizativo, da maçonaria entre nós verificou-se logo em seguida à Revolução Francesa, como no capítulo imediato se verá. Este acontecimento pôs em marcha por toda a Europa, com ímpeto maior ou menor, as forças políticas, sociais e culturais voltadas para a ideia de mudança, que desde longa data vinham a acumular-se. O ímpeto, isto é, o impacto revolucionário, foi proporcional à acumulação dessas forças. E no nosso país a modéstia da acumulação explica, melhor do que a intensidade da repressão, segundo me parece, a modéstia do impacto, em termos de mobilização de massas ou avanço para o poder na sociedade, no estado ou na cultura.

As forças produtivas materiais da burguesia não acusam entre nós, até aos meados do século XVIII, um progresso significativo no plano da agricultura, da indústria ou dos serviços. A indústria não artesanal passou depois por uma fase de expansão, na época pombalina sob o signo do colbertismo e na época mariana sob o signo da competividade e da modernização tecnológica. A expansão tem, no entanto, um carácter não só precário, mas de âmbito económica e geograficamente restrito. Não deu o ser a uma burguesia industrial quantiosa e poderosa, que de qualquer modo pudesse comparar-se com a sua congénere da Inglaterra, da França, dos Países-Baixos ou da própria Alemanha ocidental.

Houve também, é verdade, um robustecimento dos estratos burgueses ligados ao comércio externo. O fenómeno restringiu-se porém à faixa do litoral, com os principais polos em Lisboa e no Porto, e processou-se na base ou da reexportação de produtos coloniais ou da importação de tecidos e géneros alimentares. $O$ comércio interno, pela sobrevivência das estruturas senhoriais, manteve-se estático e 
como actividade sem margem para acumulação significativa de capital e, portanto, sem capacidade apreciável de investimento nos sectores da produção $\left({ }^{1}\right)$.

A imobilidade estrutural e económica foi favorável, por contra-reflexos de vária ordem, ao desenvolvimento da burguesia intelectualizada e à intelectualização de sectores apreciáveis da nobreza urbana. Estes estratos populacionais ocupavam-se, pela maior parte, na clericatura, no ensino, nas profissões liberais, no alto negócio, e na função pública civil e militar. $\mathrm{O}$ papel político de tais estratos, em avanço desde o reinado de D. João $\mathrm{V}$, acelerou-se, pelo prisma da importância, ao longo da época pombalina. Havia dentro deles, porém, contradições evidentes. A opção ideológica iluminista, largamente preponderante entre os seus membros desde o limiar do último quartel do século, dividiu-se perante a opção económico-social, pendendo um sector para o lado dos interesses da classe hegemónica e outro para o lado dos interesses da classe subalterna fundamental. A divisão criou, assim, no país evoluído, um certo espaço tanto para o radicalismo ideológico como para o desejo de mudanças.

As tendências em foco poderiam denominar-se, respectivamente, de revolucionária e de reformista. Articulavam-se ambas com uma outra, maior do que qualquer delas, alimentada pelos descontentamentos em face do «status quo» e que ansiava por uma melhor gestão do estado. $\mathrm{Na}$ ordem de grandeza, excedia-a entretanto o conservantismo do "Portugal Velho», a passividade da baixa burguesia provincial e a alienação das camadas populares.

Compensou-se, de certo modo, a escassa acumulação de forças económico-sociais burguesas, em termos de espaço nacional, com a sua acumulação no aparelho de estado e no plano da cultura. O aparelho de estado caiu, durante a segunda metade do século XVIII e princípios do século XIX, nas mãos de agentes oriundos da nobreza secundária e da burguesia. Por outro lado, a cultura escolar e a cultura extra-escolar, após a reforma do ensino preparatório (1759) e a do ensino superior (1772), impeliam para a desfundamentação teórica

(1) Sobre a matéria deste número e do anterior, expus o meu pensamento na introdução sociopolítica ao curso de História dos Movimentos Ideológicos em Portugal nos Séculos $X I X-X X$, regido no ano lectivo de 1976-1977. O texto, com alguns desenvolvimentos e o necessário aparato bibliográfico, aparecerá brevemente. 
da ordem política tradicional. No mesmo sentido caminhava também a Academia Real das Ciências (1779).

14. A Pré-Revolução e a Revolução Francesa de 1789 foram encaradas favoravelmente pelo nosso Governo e pelo embaixador de Portugal em Paris, D. Vicente de Sousa Coutinho. O favor da interpretação derivou de um puro equívoco: que, no essencial, não estariam em causa o sistema monárquico absolvtista, nem o resíduo das estruturas sócio-económicas da França, nem mesmo a reformulação da cultura europeia assimilada (e coproduzida) pelo iluminismo católico; que tão-só estariam em causa a modernização desses aparelhos, o colapso sociopolítico da igreja e da alta nobreza, o enfraquecimento da Gália enquanto grande potência.

Era a interpretação imediatamente possível pelos homens públicos de formação pombalina, estrangeirados ou não, como Sousa Coutinho, Luís Pinto, José de Seabra da Silva, etc. (1). E foi essa imagem dos acontecimentos, aliás desfasada da realidade (como esses políticos posteriormente viriam a reconhecer), que Sousa Coutinho veiculou para a corte, Luís Pinto aplaudiu, e a Gazeta de Lisboa reflectiu durante alguns meses, desencadeando processos ideológicos de oposição e processos de adesão aos princípios revolucionários, por pessoas de vária extracção social, na nossa terra (2).

Não teve longa duração a expectativa benevolente de alguns ministros de D. Maria I, nem o seu entusiasmo reformista (3). Em

(1) D. Vicente de Sousa Coutinho era embaixador de Portugal em Paris, desde 1772; Luís Pinto de Sousa Coutinho, depois de representante de Portugal na Inglaterra de 1770 a 1787 , desempenhava desde 1788 o cargo de ministro e secretário dos negócios estrangeiros e da guerra; José de Seabra da Silva, secretário de estado infeliz na época pombalina, exercia desde 1788 as funções de ministro e secretário do reino.

(2) O tema deste número e do anterior foi abordado já por Latino Coelho, História política e militar de Portugal, vol. 2. ${ }^{\circ}$, pp. 151-206, e CaEtano Beirão, $A$ rainha $D$. Maria $I$, pp. 365-95. Retomo-o, entretanto, com a publicação dos respectivos documentos, no livro Portugal e a Revolução Francesa, em adiantada preparação.

(3) Entre as providências legislativas de feição reformista, merecem especial destaque a carta régia de 3 de Fevereiro de 1789, que activou o Novo Código de direito público, e a lei de 19 de Julho de 1790, que cerceou os direitos administrativos dos donatários e alcaides-mores das terras. 
Abril de 1790, sopravam já outros ventos no gabinete mariano. Os responsáveis descobriram, com uma clareza perfeita, que os acontecimentos franceses constituíam a expressão de uma mudança qualitativa, profunda e contagiosa, e que essa mudança punha em risco, simultaneamente, a ordem tradicional portuguesa, a segurança externa do estado e o estatuto colonial da nação.

Toda a política diplomática posterior, como na esfera interna todo o movimento dos aparelhos de estado (a igreja incluída), visaram o bloqueio da Revolução, quer nas suas sequelas desestabilizadoras do sistema existente, quer nas suas ameaças à continuidade do nosso estatuto de potência ultramarina. É isso que inspira as negociações multilaterais para uma (não lograda) tríplice aliança de Portugal, Espanha e Inglaterra, e é o que inspira, à falta de melhor, os acordos bilaterais estabelecidos com estes reinos (1), em 1793.

\section{MAÇONISMO E PROGRESSISMO}

15. Quando ressoaram na casa lusitana os ecos da Revolução de 89 , as forças propulsoras da ideologia liberal eram modestas, em termos não só de condicionalismos, mas de massas interessadas. Achavam-se incomparavelmente abaixo das forças sociais e culturais de repulsão. Havia, no entanto, fracções da classe burguesa e das camadas intelectuais, que, mesmo sem o confessarem e às vezes até porventura sem disso se aperceberem, apostavam na mudança ou estavam, pelo menos, predispostas para ela. O maçonismo, para se expandir, tinha pois de vencer resistências que não eram só políticas; contudo, deparava-se-lhe também, simultaneamente, nos grandes centros urbanos, uma base possível de acolhimento e de apoio. E nisso consistia, por um lado, a sua fraqueza, mas por outro a sua força.

$\mathrm{Na}$ conjuntura histórica lusíada da última década do século XVIII e primeira do século XIX, a expansão da maçonaria não era exequível - - nem pelos adversários era inteligível - fora de um processo global. O impacto das ideias liberais tornava o desenvolvimento da Sociedade inseparável do desenvolvimento do jacobinismo e dos conflitos sócio-

(1) Desenvolvo e fundamento os tópicos deste número e do anterior na já citada Introdução à história dos movimentos ideológicos em Portugal nos séculos $X I X-X X$. 
-económicos a que este se colara na terra portuguesa. Desse modo o compreendeu Pina Manique, como se verifica por estas linhas:

«Nos tempos em que as sociedades maçónicas estavam envolvidas no segredo e no mistério, que faz o seu principal carácter, foi preciso à igreja e ao estado o preveni-las como propagadoras de opiniões anti-religiosas e anti-sociais.... $\mathrm{O}$ provérbio qui male agit, odit lucem, dava suficiente fundamento para se não perderem de vista estas associações; e a indiferença das religiões, que admitia esta Ordem, florescente particularmente nos países em que o catolicismo não era a única religião ou em que se principiava a inquinar com princípios ímpios e heréticos, dava cabais suspeitas da sua imoralidade. Hoje porém que se têm propagado as suas máximas irreligiosas e revolucionárias, e em que, à face de graves escritores que comprovam com os factos as suas asserções e que mostram a história do tempo, aquelas suspeitas e receios se têm tornado em certeza de que estas associações são os focos da imoralidade e revolução. Os principais propagadores das doutrinas do século são nelas envolvidos: a sua linguagem, os seus discursos e as suas razões, que têm feito nestes tempos de guerra de opinião, deve ser a ciência das lojas. $\mathbf{O}$ cuidado de dirigirem das lojas-madres emissários a transplantar esta seita e com ela as suas doutrinas em todo o mundo, tem sido um dos principais meios de as tornarem gerais e de disporem com elas os ânimos para conseguirem os seus fins») (1).

Nada nos indica que as lojas tivessem sido a estrutura organizativa ou a matriz incubadora da ideologia em luta com o Portugal Velho. Entraram, sem dúvida, com uma quota, na produção do fenómeno embora, segundo todas as aparências, uma quota relativamente pouco importante. Entrar com uma quota não significa porém que o jacobinismo e o activismo progressista tivessem nelas a fonte da sua doutrina ou da sua dinâmica. Afigura-se, ao invés, que a correlação da maçonaria com as ideologias e actividades revolucionárias foi o produto de um arrastamento da primeira pelas segundas.

É esse arrastamento que nos explica que os protagonistas do maçonismo se confundam, por vezes, com os agenciadores do liberalismo, confluindo no mesmo indivíduo os atributos de ambos. Mas deve-se também à prioridade e autonomia do surto filosofista e revolucionário, o facto de o maçonismo se revelar em Portugal só escassamente doutrinado e politizado à hora da Revolução Francesa. E deve-se-lhe, por outro lado, que, à medida do reflexo desta, se mostre crescente, mas não uniformemente, contaminado pelo jacobinismo.

(1) Ofício de Pina Manique para o marquês de Ponte do Lima, de 8 de Agosto de 1799, apud Luz SoRIANo, ob. e época cits., t. 3. ${ }^{\circ}$, pp. 71-72. 
16. Os documentos não permitem atribuir, seja a Filinto e ao respectivo círculo, seja a Anastácio e aos seus companheiros de Valença ou de Coimbra, ligações ou actividades maçónicas. Um contemporâneo, no entanto, o satírico António Lobo de Carvalho, alcunhando-os de "filósofos de caldo de unto e borôa", conotou-os de pedreirismo (1). E a conotação, se não abona a objectividade do conotado, inculca pelo menos que a «inteligência» reaccionária estava atenta ao fenómeno maçónico e o aliançava com o deismo.

A maçonaria francesa, ou fosse por determinação do Grande Oriente, ou fosse apenas por iniciativa pessoal de alguns militantes, teve uma parte no relançamento da Ordem em Lisboa, porventura também no Porto, em vésperas ou imediatamente após a Revolução de 89. Um dos emissários vindos à nossa corte para esse efeito - desconhece-se com que recomendações e de quem ou para quem - foi François Gilley Angereau, em 1788. Detectada, no entanto, pela Polícia, a sua presença, falhou por completo na missão (2). Falhou, do mesmo modo, a tentativa de José Bálsamo, o auto-intitulado conde de Cagliostro, criador da maçonaria egípcia (3), para a estabelecer na capital, também naquele ano $\left.{ }^{4}\right)$. Foi mais feliz do que eles - se bem, como no capítulo seguinte se verá, não muito mais - Jean-Josset Dorquigni. Regressado da tarefa na Madeira, instalou-se em Lisboa, onde conseguiu permanecer na actividade maçónica durante algum tempo.

(1) «.... que dê Portugal livres-pedreiros, / Que à fé cristã abrissem o jazigo / / No sórdido país dos sardinheiros, / É caso raro...." (António Lobo de CaRvalho, Poesias joviais e satíricas, Cádis, 1852, p. 67).

(2) Foram vãos todos os esforços para localizar nos fundos da Inquisição, da Intendência de Polícia e do Ministério do Reino, no ANTT, o sumário ou processo relativo à sua actuação.

(3) Não me alargarei sobre a personalidade e acção de José Bálsamo, nem tão-pouco sobre o rito egípcio. O leitor interessado poderá esclarecer-se nas sínteses de Pierre Chevalier, Histoire de la Franc-Maçonnerie Française, vol. 1..$^{\circ}$, pp. 257-63; Gérard Serbanesco, Histoire de la Franc-Maçonnerie universelle, t. 2. ${ }^{\circ}$, pp. 319-49; Robert Amadou, Cagliostro, in «Dictionnaire universel de la Franc-Maçonnerie», t. $1 .^{\circ}$, pp. 185-95.

(4) O ano de 1788 é a única interpretação consentida pela referência de Pina Manique, no ofício anteriormente citado. De contrário, atendendo à data da sua libertação em França, dos exílios na Inglaterra e na Suíça, e da partida para Itália, seria tentado a fixar a sua presença em Portugal entre 1786 e 1788, mais provavelmente antes da partida para a Suíça (Março de 1787). 
Carece, pois, de fundamento a tese corrente na historiografia reaccionária - aliás também na historiografia maçónica - , segundo a qual a Sociedade teria sido a verdadeira mola do avanço filosofista em Portugal, quer antes, quer depois dos acontecimentos revolucionários da França. E carece igualmente de base a teoria maniquista que explica o relançamento da Ordem na nossa terra como proeza de agentes estrangeiros, ao serviço de interesses internacionais. Bom ou mau, o relançamento é na essência um produto nacional e constitui a sequela de um processo histórico também nacional. A maçonaria não nos aparece assim, nesta época, como a mediação organizativa dos avanços ideológicos e políticos em desenvolvimento na pátria, mas antes como estrutura que se desenvolve à margem desses avanços e com atrazo em relação a eles.

J. S. DA Silva Dias 